\title{
Ю.І. Комісаренко
}

\section{ДЕФІЦИТ ВІТАМІНУ Ф І ЙОГО РОЛЬ У РОЗВИТКУ ПОРУШЕНЬ ОБМІНУ РЕЧОВИН ЗА ЦУКРОВОГО ДІАБЕТУ}

\author{
Національний медичний університет ім. О.О. Богомольия, Київ
}

Сучасні наукові уявлення про біологічну роль вітаміну $\mathrm{D}_{3}$ в організмі останніми роками поповнились новими відомостями, що значною мірою змінили погляди на значення цього вітаміну. Дефіцит вітаміну D є загальною та досить розповсюдженою проблемою, що має виражені клінічні наслідки. За даними James W.P.T., у світі нараховується 1 мільярд людей, які мають недостатність вітаміну $\mathrm{D}_{3}[1]$.

Вітамін D традиційно відносять до групи жиророзчинних вітамінів. Проте, на відміну від усіх інших вітамінів, вітамін D не $є$ власне вітаміном у класичному сенсі цього терміну, бо він:

а) біологічно не активний;

б) за рахунок двоступінчатого метаболізму в організмі перетворюється на активну - гормональну форму;

в) справляє різноманітні біологічні ефекти за рахунок взаємодії зі специфічними рецепторами, локалізованими у ядрах клітин багатьох тканин і органів. У цьому сенсі активний метаболіт вітаміну D поводиться як істинний гормон, через що і отримав назву "D-гормон". Але за історичною традицією його називають "вітамін D".

Цей термін - "вітамін D" - $є$ певною мірою умовним. Він об'єднує групу існуючих у природі подібних за хімічною будовою (секостероїди) речовин:

- вітамін $D_{1}$ (так було названо відкриту 1913 року E.V. McCollum'om у жирі з печінки тріски речовину, що є сполукою ергокальциферолу та люмістеролу у співвідношенні 1:1);

- вітамін $\mathrm{D}_{2}$ - ергокальциферол, що утворюється 3 ергостеролу під дією сонячного світла, головним чином у рослинах, $€$ однією з двох (поруч із вітаміном $\mathrm{D}_{3}$ ) найрозповсюдженіших форм вітаміну D;

- вітамін $\mathrm{D}_{3}$ - холекальциферол, що утворюється в організмі тварин під дією сонячного світла з 7-дегідрохолестерину; саме його розглядають як "істинний" вітамін D, тоді як інші представники цієї гру- пи вважають модифікованими похідними вітаміну D.

Загальновизнаний класичний ефект вітаміну $\mathrm{D}_{3}$ в організмі - це підтримка рівня кальцію та фосфору у сироватці крові у вузьких фізіологічних межах, що забезпечує нормальне функціонування усіх органів і тканин.

Традиційна характеристика вітаміну $\mathrm{D}_{3}$ як гормону-регулятора мінерального обміну останнім часом доповнилася новими даними, що дозволили суттєво змінити погляд на фізіологічну роль цього вітаміну [2]. Відкриття рецепторів до гормонально активних форм вітаміну $\mathrm{D}_{3}$ та ї синтезу у клітинах нетрадиційних для цього вітаміну органів і тканин передбачає більш широкий спектр фізіологічного ефекту вітаміну [3].

Розглядаються два механізми впливу вітаміну $D_{3}$ на фізіологічні процеси: на рівні геному та негеномні ефекти. На рівні геному метаболіти вітаміну $\mathrm{D}_{3}$ проявляють фізіологічний ефект шляхом, близьким до дії стероїдних гормонів [4]. Другий механізм дії вітаміну $\mathrm{D}_{3}$ проявляється через мембрану.

Було продемонстровано, що холекальциферол прямо або опосередковано регулює синтез ліпідів, білків, гормонів, рецепторних білків. Встановлено, що вітамін $\mathrm{D}_{3}$ бере участь у проліферації та диференціації клітин багатьох органів і тканин, у процесі модуляції імунної відповіді, функціональної активності серцево-судинної системи, шлунково-кишкового тракту, клітин м'язової тканини [5]. Через це його препарати широко застосовуються для профілактики та лікування не лише порушень мінерального обміну. Так, отримано позитивні ефекти від лікування холекальциферолом і його активними метаболітами імунодефіцитних станів, анемії, цукрового діабету, різних патологічних станів печінки, шлунково-кишкового тракту, серцевосудинної системи, туберкульозу, злоякісних пухлин молочних залоз і кишечника тощо.

Розширення уявлень про роль вітаміну $\mathrm{D}_{3}$ стало результатом відкриття рецепторних біл- 
ків у клітинах органів і тканин, не залучених до мінерального обміну та обміну вітаміну, а також можливості синтезу активних метаболітів вітаміну $D_{3}$ цими клітинами. Наявність таких рецепторів було показано, зокрема, у $\beta$-клітинах підшлункової залози, що дозволяє розглядати їх як клітини-мішені для вітаміну $D_{3}$ [6].

На роль вітаміну $D_{3}$ у здійсненні функцій підшлункової залози вказують індуковані 1,25дигідрохолекальциферолом $\left(1,25(\mathrm{OH})_{2} \mathrm{D}_{3}\right)$ морфологічні зміни $\beta$-клітин з одночасним підвищенням їх активності, а також наявність високо афінного рецептора, що локалізується у ядрах $\beta$-клітин підшлункової залози. Після внутрішньочеревного введення щурам ${ }^{3} \mathrm{H}-$ $1,25(\mathrm{OH})_{2} \mathrm{D}_{3}$ або інкубації острівців підшлункової залози з дигідроксиметаболітом вітаміну $\mathrm{D}_{3}$ у дослідах in vitro мітка концентрувалася у ядрах $\beta$-клітин у кількості 400 нмоль/мг ДНК. Причому здатність накопичувати $1,25(\mathrm{OH})_{2} \mathrm{D}_{3}$ мають лише клітини, що містять інсулін, тобто $\beta$-клітини, але не клітини, які містять глюкагон або соматостатин [7]. Характерним є те, що $1,25(\mathrm{OH})_{2} \mathrm{D}_{3}$ зв'язується як із клітинами, що розвиваються, так і зі зрілими $\beta$-клітинами тканини підшлункової залози, що узгоджується з участю гормону у проліферації та диференціюванні цих клітин, а також регуляції їх функціональної активності. Тому порушення забезпеченості організму активними метаболітами вітаміну $D_{3}$ може бути однією з основних причин зміни рівноваги між процесами деструкції $\beta$-клітин та їх здатністю регенерувати, що призведе до зменшення їх кількості, а це, як відомо, лежить в основі розвитку діабету 1-го типу.

Крім даних про вплив гормонально активних форм вітаміну $D_{3}$ на процеси проліферації та диференціювання, велике значення мають відомості про зміну різних функціональних властивостей цих клітин під впливом зазначених метаболітів. Першим етапом такої дії $€$ зв'язування $1,25(\mathrm{OH})_{2} \mathrm{D}_{3}$ із рецепторними білками $\beta$ клітин. Утворений гормон-рецепторний комплекс переноситься у ядро клітини та вступає у взаємодію з певними ділянками молекули ДНК. Результатом цієї взаємодії є біосинтез нових молекул мРНК і трансляції відповідних білків, що беруть участь у гормональній відповіді [7].

В експерименті доведено, що 1,25(OH) ${ }_{2} \mathrm{D}_{3}$ регулює рівень глюкози у крові. Одноразове введення його щурам, позбавленим вітаміну D, підвищує їх толерантність до глюкози та збіль- шує секрецію інсуліну. Подальші дослідження у цьому напрямку показали, що нормалізація толерантності до глюкози відбувається досить швидко та дозозалежно. Ефект 1,25(OH) ${ }_{2} \mathrm{D}_{3}$ досягає максимуму через 3 години після його введення та знижується зі збільшенням його дози.

Дещо інакше проявляють свою дію інші метаболіти вітаміну $D_{3}$ : 25-гідроксихолекальциферол $\left(25(\mathrm{OH}) \mathrm{D}_{3}\right)$ і 24,25-дигідроксихолекальциферол $\left(24,25(\mathrm{OH})_{2} \mathrm{D}_{3}\right)$. Після введення хворим із дефіцитом вітаміну D ці метаболіти, не змінюючи толерантності до глюкози, призводили до нормалізації секреції інсуліну та часткового пригнічення секреції глюкагону [8].

Іншою причиною порушення секреції інсуліну $€$ зміна функціональної активності $\beta$-клітин, як це відбувається за цукрового діабету 2-го типу (ЦД-2). Механізм зміни цієї активності, можливо, пов'язано з модифікацією ліпідних компонентів мембран клітин, синтез яких регулюється вітаміном $D_{3}$. Було також показано, що у деяких випадках причиною розвитку ЦД-2 є синтез аномальної, біологічно менш активної молекули інсуліну [9]. Враховуючи, що вітамін $D_{3}$ регулює синтез цього гормону на рівні геному, можна припустити, що його недостатність в організмі є однією з причин синтезу аномального інсуліну.

Важливу роль в етіології ЦД-2 можуть грати порушення взаємодії інсуліну та його рецепторів. Наразі рецептор інсуліну досить добре описано, клоновано його ген. Рецептор складається $з$ двох позаклітинних $\alpha$-субодиниць із молекулярною масою 135 кД. Альфа-субодиниці, що мають властивість зв'язувати інсулін за допомогою дисульфідних містків, зв'язано з двома $\beta$-субодиницями (95 кД), які мають гідрофобну трансмембранну зону та внутрішньоклітинний домен, що несе декілька тирозинових залишків, тирозинкіназу та ділянку, яка зв'язує АТФ. Показано, що інсулін, зв'язуючись з $\alpha$-субодиницями, активує тирозинову протеїнкіназу $\beta$-субодиниці та здійснює фосфорилювання тирозинових залишків цієї субодиниці. Вважають, що активація кінази $\alpha$-субодиниці може бути залученою до передачі інсулінового сигналу, можливо, за механізмом фосфорилювання/дефосфорилювання. У разі найбільшої стійкості до інсуліну процес передачі сигналу від інсулінзв'язуючої ділянки $\alpha$-субодиниці рецептора до кінази, очевидно, порушено в одному або декількох місцях [5]. 
Необхідно відзначити, що активність рецепторів інсуліну в клітині залежить від мікров'язкості мембран, тому якісні або кількісні зміни ліпідних компонентів, що відбуваються на тлі D-гіповітамінозу, можуть бути однією з причин, які ведуть до порушення зв'язування інсуліну 3 рецепторними білками [10].

Крім того, вітамін $D_{3}$ впливає на синтез рецепторів до цього гормону. Так, у дослідженнях на культурах клітин було показано, що вітамін $\mathrm{D}_{3}$ збільшує кількість рецепторів інсуліноподібного чинника росту 1 , які функціонально є близькими до рецепторів інсуліну та містять інсулінозалежну тирозинову протеїнкіназу [11].

У свою чергу, інсулін стимулює синтез гормонально активних метаболітів вітаміну $\mathrm{D}_{3}$. Проте механізм цього процесу остаточно не вивчено. Окремі автори вважають, що інсулін впливає на активність гідроксилазних ферментів опосередковано, через регуляцію внутрішньоклітинного рівня кальцію внаслідок стимуляції активності $\mathrm{Ca}^{2+}, \mathrm{Mg}^{2+}$-АТФази, а також шляхом зміни чутливості цих ферментів до фосфору.

Отже, цілком ймовірно, що така взаємодія інсуліну та активних форм вітаміну $D_{3}$ відкриває цікаві перспективи в плані їх об'єднаної дії на порушення обмінних процесів за цукрового діабету, що можуть мати місце за умов пошкодження однієї з систем.

За експериментального ЦД концентрація $25(\mathrm{OH}) \mathrm{D}_{3}, 24,25(\mathrm{OH})_{2} \mathrm{D}_{3}$ та $1,25(\mathrm{OH})_{2} \mathrm{D}_{3}$ у сироватці крові щурів знижувалася порівняно з їх рівнем у контрольних тварин на 57\%, 62\% і 50\% відповідно. Причиною зниження рівня активних метаболітів вітаміну $D_{3}$ за цукрового діабету стало порушення його всмоктування у тонкому кишечнику внаслідок збільшення у клітинах вмісту холестерину, фосфоліпідів і загальних ліпідів на 58\%, 75\% і 64\% відповідно, а також порушення обміну холекальциферолу в організмі.

Відомо, що 70\% холекальциферолу з кровобігу поглинається печінкою, де відбувається перший етап його гідроксилювання з утворенням 25(OH)D $D_{3}$, який, крім виконання певної фізіологічної функції в організмі, $€$ також субстратом у нирках гормонально активних метаболітів вітаміну $\mathrm{D}_{3}-1,25(\mathrm{OH})_{2} \mathrm{D}_{3}$ і $24,25(\mathrm{OH})_{2} \mathrm{D}_{3}$. Відомо, що за ЦД відбуваються виражені деструктивні зміни тканини печінки, що може бути причиною порушення як транспорту холекальциферолу у печінці та його розподілу по клітинах цього органа, так і порушення його гідрок- силювання внаслідок пригнічення активності ферментів. Виявилося, що за ЦД не лише на 45\% зменшується поглинання холекальциферолу печінкою, а й змінюється його розподіл по клітинах печінки [11].

Згідно з даними літератури, вітамін $D_{3}$ з кровобігу транспортується як у гепатоцити, де розташовано гідроксилазні ферменти вітаміну $\mathrm{D}_{3}$, так і у ретикулоцити, які депонують холекальциферол [14]. Такий розподіл вітаміну $D_{3}$ по клітинах печінки має глибокий фізіологічний сенс: створюються оптимальні умови для його гідроксилювання, оскільки активність ферментів пригнічується самим вітаміном $\mathrm{D}_{3}$, крім того, накопичення вітаміну $D_{3}$ у ретикулоцитах і його подальший поступовий транспорт у гепатоцити забезпечує підтримку його фізіологічного рівня впродовж 3-4 міс. [12].

На тлі цукрового діабету, ймовірно, за рахунок структурних змін мембран клітин, порушується не лише поглинання вітаміну $D_{3}$ гепатоцитами, але і його транспорт із ретикулоцитів. Крім того, причиною зменшення забезпеченості організму активними метаболітами вітаміну $D_{3}$ за ЦД є пригнічення вітамін-D -25 -гідроксилазної системи печінки. За даними літератури, ферменти, які гідроксилюють вітамін $D_{3}$ у 25-му положенні, розташовано у мітохондріях і мікросомах гепатоцитів [11]. Мікросомальний фермент функціонує за фізіологічних рівнів вітаміну $D_{3}$. Активність цього ферменту зі збільшенням концентрації вітаміну $D_{3}$ в організмі знижується, він має високу специфічність, але низьку ємність зв'язування субстрату [11].

На відміну від ферменту мікросом, вітамін$\mathrm{D}_{3}$-25-гідроксилаза мітохондрій має низьку специфічність, але високу ємність зв'язування субстрату. Цей фермент діє за високих концентрацій вітаміну $D_{3}$. Вважають, що у процесі гідроксилювання вітаміну $D_{3}$ відбувається розподіл функцій між двома типами гідроксилаз залежно від концентрації субстрату.

За ЦД, мабуть, внаслідок зміни структурних компонентів мембран субклітинних фракцій, від-

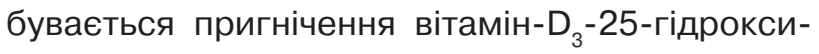
лазної системи печінки, причому найбільш виражено - мікросомальної вітамін-D -25 -гідроксилази [13].

Наведені вище дані дозволяють дійти висновку, що причинами зниження рівня активних метаболітів в організмі за ЦД є зниження поглинання вітаміну $D_{3}$ у слизовій оболонці тонко- 
го кишечника, зменшення його поглинання печінкою, порушення транспорту вітаміну $D_{3}$ y гепатоцити, а також пригнічення вітамін- $D_{3}-25$ гідроксилазної системи печінки.

Сьогодні існує декілька класифікацій ступеня забезпеченості вітаміном D, найбільш розповсюджену наведено у табл. 1.

Порушення обміну вітаміну $D_{3}$ за цукрового діабету супроводжується змінами мінерального обміну. Свою дію на мінеральний обмін вітамін $\mathrm{D}_{3}$ проявляє насамперед шляхом регуляції син-

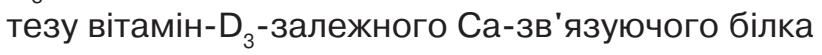
(Са-ЗБ). За експериментального ЦД різко знижувався рівень Са-ЗБ у тонкому кишечнику. Концентрація $\mathrm{Ca}^{2+}$ у сироватці крові за некомпенсованого ЦД також знижувалась і відновлювалася після введення інсуліну.

Необхідно підкреслити, що зниження вмісту Са-ЗБ у дванадцятипалій кишці корелювало зі зменшенням у плазмі крові концентрації загального $1,25(\mathrm{OH})_{2} \mathrm{D}_{3}$ на тлі нормального вмісту $25(\mathrm{OH}) \mathrm{D}_{3}$. В епітелії тонкого кишечника зменшувалася кількість рецепторів до 1,25(OH) ${ }_{2} \mathrm{D}_{3}$ зі збереженням високої спорідненості до цього метаболіту вітаміну $\mathrm{D}_{3}$. Можливо, що однією з причин зниження всмоктування $\mathrm{Ca}^{2+}$ і Са-ЗБ у тонкому кишечнику, рівня $1,25(\mathrm{OH})_{2} \mathrm{D}_{3}$ у сироватці крові щурів із діабетом може бути збільшення вживання ними кальцію з їжею.

Найбільш вивченим проявом ефекту вітаміну $\mathrm{D}_{3}$ на білковий обмін $€$ його дія на синтез білків слизової тонкого кишечника. Відомо, що клітини цього органа відповідають на надходження у них активних метаболітів вітаміну $D_{3}$ утворенням специфічного Са-зв'язуючого білка (кальбіндіну), що забезпечує перенесення $\mathrm{Ca}^{2+}$ крізь слизову тонкого кишечника. Вперше виявлений у кишковому епітелії курчат Са-ЗБ у подальшому було виділено як із кишечника інших видів тварин, так і з інших тканин. Зокрема, значні кількості вітамін$\mathrm{D}_{3}$-залежного Са-ЗБ було ідентифіковано також у кірковому шарі нирок, у плаценті, яйцепроводі птахів, кістковій тканини, а також у низці залоз внутрішньої секреції [5].

Вітамін D не лише сприяє синтезу de novo білків, що належать до розряду Са-зв'язуючих, але й підсилює синтез інших білків. У дослідженнях із застосуванням мічених амінокислот було продемонстровано стимулюючий ефект вітаміну $D_{3}$ на включення мічених лізину та гліцину у сумарні білки субклітинних фракцій слизової оболонки тонкого кишечника курчат із дефіцитом вітаміну $\mathrm{D}_{3}$.

Очевидно, що в умовах недостатності вітаміну $D_{3}$ відбувається значне порушення механізму біосинтезу білків de novo в ентероцитах. На тлі D-гіповітамінозу порушується всмоктування амінокислот у кишечнику, змінюється вільний фонд амінокислот, що призводить до виражених зсувів в азотистому балансі.

Крім регуляції синтезу Са-ЗБ, вітамін $D_{3}$ впливає на синтез білків транспортної системи катіонів, що мають АТФазну активність, наприклад $\mathrm{Ca}^{2+}$-АТФазу і $\mathrm{Na}^{+}, \mathrm{K}^{+}$-АТФазу. Продемонстровано, що холекальциферол може збільшувати активність $\mathrm{Ca}^{2+}$-АТФази за рахунок індукції біосинтезу додаткових молекул цієї системи. Наявність такої стимуляції 1,25(OH) ${ }_{2} \mathrm{D}_{3}$ кальцієвого насоса встановлено у тонкому кишечнику, нирках і кістковій тканині [15].

Вітамін $D_{3}$ і його активні метаболіти регулюють також активність лужної фосфатази у слизовій тонкого кишечника, кістковій тканині та нирках, а також низки інших ферментів. Відомо, що за D-дефіцитних станів відбувається зниження активності лужної фосфатази у слизовій тонкого кишечника, яка відновлюється після введення вітаміну $D_{3}$.

Таблиця 1

Класифікація ступеня забезпеченості вітаміном D

\begin{tabular}{|c|c|c|c|}
\hline \multirow{2}{*}{ № } & \multicolumn{2}{|c|}{ Концентрація 25(OH)D } & \multirow{2}{*}{ Діагноз } \\
\hline & нг/мл & $\begin{array}{r}\text { нмоль/л } \\
\end{array}$ & \\
\hline 1. & $>40,0-100$ & $>100,0-250$ & Норма \\
\hline 2. & $60,0-90,0$ & $150,0-225,0$ & Оптимальний рівень \\
\hline 3. & $31,0-<40,0$ & $77,5-<100,0$ & D-гіповітаміноз \\
\hline 4. & $16,0-<30,0$ & $40,0-<75,0$ & D-вітамінна недостатність \\
\hline 5. & $<15,0(<20,0)$ & $<37,5(<50,0)$ & D-вітамінний дефіцит \\
\hline 6. & $>300,0$ & $>750,0$ & D-гіпервітаміноз \\
\hline 7. & $>100,0$ & $>250,0$ & Гарантія широкого кола безпеки \\
\hline
\end{tabular}


Дані літератури щодо зміни вмісту та біосинтезу ліпідів у тканині тонкого кишечника на тлі D-дефіцитних станів різняться. 3 одного боку, автори наводять дані, які свідчать, що за D-гіповітамінозу у мембранах ентероцитів щурів знижується рівень загальних ліпідів і холестерину та дещо підвищується вміст фосфоліпідів і неетерифікованих жирних кислот [16]. 3 іншого боку, вважають, що після введення вітаміну $\mathrm{D}_{3}$ або його активних метаболітів у слизовій кишечника суттєво збільшується вміст фосфоліпідів і змінюється склад жирних кислот. Висловлюється думка, що вітамін $\mathrm{D}_{3}$ стимулює синтез фосфоліпідів слизової тонкого кишечника шляхом збільшення синтезу специфічних фосфатидаз.

Неоднозначними є також результати дослідження впливу вітаміну $\mathrm{D}_{3}$ на ліпідний склад кісткової тканини. За даними одних авторів, за D-дефіцитного стану відбувається збільшення вмісту в цій тканині загальних ліпідів, фосфогліцеридів, тригліцеридів і холестерину. Інші автори відзначають на тлі D-гіповітамінозу збільшення вмісту проміжних продуктів біосинтезу холестерину. Проте вміст холестерину зменшується у зв'язку з порушенням його синтезу на стадії відновлення подвійного зв'язку десмостерину у положенні C24. Деякі автори вказують на зниження вмісту загальних ліпідів, фосфоліпідів і холестерину в плазмі крові на тлі дефіциту в організмі вітаміну $\mathrm{D}_{3}$.

Наші дані, наведені у табл. 2, демонструють збільшення рівня загальних ліпідів і холестеролу у крові щурів з експериментальним діабетом на тлі дефіциту вітаміну $\mathrm{D}_{3}$ із тенденцією до нормалізації показників після додавання вітаміну $\mathrm{D}_{3}$ в їжу.

Отримані результати повною мірою відображають як серйозність проблеми, так і багатогранність взаємодії гормональної системи під- шлункової залози та дії вітаміну $\mathrm{D}_{3}$. Аналіз даних літератури продемонстрував, що однією 3 можливих причин протиріччя результатів може бути проведення досліджень за патології різного ступеня.

Розширення наших знань про роль вітаміну $\mathrm{D}_{3}$ в організмі в нормі та на тлі патології розкриває перспективи клінічного використання цього вітаміну у профілактиці та лікуванні цукрового діабету.

\section{ЛITEPATУРA}

1. James W.P.T. 22nd Marabou Symposium: The changing faces of vitamin D / W.P.T. James // Nutr. Rev. - 2008. - Vol. 66. - P. 286-290.

2. Panda D.K. Targeted ablation of the 25-hydroxyvitamin D 1 alpha-hydroxylase enzyme: evidence for skeletal reproductive and immune dysfunction / D. K. Panda, D. Miao, M. L. Tremblay, J. Sirois [et al.] // Proc. Natl. Acad. Sci. USA. 2001. - Vol. 98, №13. - P.7498-7503.

3. Rojas-Rivera $\mathrm{J}$. The expanding spectrum of biological actions of vitamin D / J. Rojas-Rivera, C. De La Piedra, A. Ramos [et al.] // Nephrol. Dial. Transplant. - 2010. - Vol. 25(9). P. 2850-2865.

4. Yamamoto $\mathrm{H}$. The caudal-related homeo-domain protein $\mathrm{Cdx}-2$ regulates vitamin $\mathrm{D}$ receptor gene expression in the small intestine / $\mathrm{H}$. Yamamoto [et al.] // J. Bone Miner. Res. - 1999. - Vol. 14, №2. - P. 240-247.

5. Maiyar A.C. Vitamin D / A.C. Maiyar, A.W. Norman // Enciclopedia of human biology. - London: Acad. Press. - 1991. - Vol. 7 - P. 859-871.

6. Clarks M. 1,25-dihydroxyvitamin D3 target cells in immature pancreatic islets / M. Clarks [et al.] / / Amer. J. Physiol. - 1987. - Vol. 253, №1. Pt. 1. P. E99-E105.

7. Haussler M.R. Vitamin D receptors: nature and functuion / M.R. Haussler // Ann. Rev. Nutrition. 1986. - Vol. 6. - P. 525-562.

8. Bikle D. Nonclassic Actions of vitamin D / D. Bikle // J. Clin. Endocrinol. Metab. - 2009. - Vol. 94(1). P. 26-34.

Таблиця 2

\section{Вплив вітаміну $D_{3}$ на ліпідний склад сироватки крові щурів з експериментальним} діабетом

\begin{tabular}{|c|c|c|c|}
\hline \multirow{2}{*}{ Досліджувані показники } & \multicolumn{3}{|c|}{ Групи тварин } \\
\hline & контроль & діабет & діабет $+\mathrm{D}_{3}$ \\
\hline Загальні ліпіди, г/л & $3,30 \pm 0,02$ & $4,80 \pm 0,20$ & $3,00 \pm 0,20^{\star}$ \\
\hline Сумарні фосфоліпіди, ммоль/л & $1,11 \pm 0,09$ & $0,87 \pm 0,02$ & $0,62 \pm 0,05$ \\
\hline Загальний холестерол, ммоль/л & $3,50 \pm 2,04$ & $5,93 \pm 0,03$ & $3,69 \pm 0,04$ \\
\hline Вільний холестерол, ммоль/л & $0,30 \pm 0,09$ & $1,12 \pm 0,02$ & $0,63 \pm 0,02$ \\
\hline Етерифікований холестерол, ммоль/л & $3,20 \pm 0,03$ & $4,92 \pm 0,03$ & $3,06 \pm 0,03$ \\
\hline
\end{tabular}

Примітка: * - вірогідна різниця з контрольною групою. 
9. Ozfirat $Z$. Vitamin D deficiency and type 2 diabetes / Z. Ozfirat, T.A. Chowdhury // Postgrad. Med. J. - 2010. - Vol. 86(1011). - P. 18-25.

10. Thacher T.D. Vitamin D insufficiency / T.D. Thacher, B.L. Clarke // Mayo Clin. Proc. - 2011. Vol. 34(1). P. E1-E6.

11. Витамин D и его роль в обеспечении здоровья детей и беременных женщин / [Лукьянова Е.М., Антипкин Ю.Г., Омельченко Л.И., Апуховская Л.И.]. - К.: Аврора-принт, 2005. - 229 с.

12. Апуховская Л.И. Метаболизм витамина D3, введенного в липосомах в печени крыс / Л.И. Апуховская, Н.Л. Хрестовая, Л. В. Антоненко // Укр. биохимический журнал. - 1991. - Т. 63, №5. C. 89-94.

13 Choi H.S. Vitamin D insufficiency in Korea - A Greater Threat to Younger Generation: The Korea National Health and Nutrition Examination Survey 2008 / H.S. Choi [et al.] // J. Clin. Endocrinol. Metab. - 2001. - Vol. 96(3). - P. 643-651.

14. Isia $G$. High prevalence of hypovitaminosis $D$ in female type 2 diabetic population / G. Isia [et al.] // Diabetes care. - 2001. - Vol. 24, №8. P. 1496

15. Ghijen W. Regulation of duodenal Ca2+-pump by calmodulin and vitamin D-dependent Ca-binding protein / W. Ghijen, C. Van Os., C. Heizmarn // Amer. J. Physiol. - 1986. -Vol. 251, №2. P. G223-G229.

16. Морозова Р.П. Липиды и протеолипиды мембран гладкого эндоплазмотического ретикулума энтероцитов крыс. Витамин-D-зависимое связывание кальция / Р.П. Морозова, В.А. Кокунин, И.А. Николенко [и др.] // Укр. биохимический журнал. - 1988. - Т. 60, № 3. - С. 60-64.

\section{PЕЗЮМЕ}

Витамин D и его роль в регуляции метаболических нарушений при сахарном диабете

\section{Ю.И. Комиссаренко}

Представлены данные о влиянии витамина $\mathrm{D}_{3}$ на углеводный, жировой и белковый обмен, а также структурно-функциональную активность $\beta$-клеток поджелудочной железы при сахарном диабете. Описаны некоторые механизмы нарушения обмена витамина $D_{3}$ при данной патологии и перспективы его клинического применения.

Ключевые слова: витамин $\mathrm{D}_{3}$, углеводный обмен, сахарный диабет, $\beta$-клетки поджелудочной железы.

\section{SUMMARY}

Vitamin D and its role in metabolic disorders regulation in diabetes mellitus

\section{Yu. Komissarenko}

Reviewed were the data pertinent of the effects of vitamin $D_{3}$ upon carbohydrate, lipid and protein metabolism, structure and function of pancreatic $\beta$-cells at diabetes mellitus. Some mechanisms of disturbance of vitamin $D_{3}$ metabolism at the above pathology and perspectives for its clinical application were described.

Key words: vitamin $D_{3}$, carbohydrate metabolism, diabetes mellitus, pancreatic $\beta$-cells. 